\title{
PENGEMBANGAN KEBIJAKAN BEHAVIOR SANITATION CULTURE PADA MASYARAKAT DESA CRANGGANG KUDUS
}

\author{
David Laksamana Caesar ${ }^{1,}$ Ervi Rachma Dewi ${ }^{2}$, Arina Hafadhotul Husna ${ }^{3}$ \\ ${ }^{1,2}$ Program Studi S1 Kesehatan Masyarakat STIKES Cendekia Utama Kudus \\ ${ }^{3}$ Program Studi S1 Keperawatan STIKES Cendekia Utama KUdus \\ E-mail: caesar.david77@gmail.com
}

\section{POLICY DEVELOPMENT OF BEHAVIOR SANITATION CULTURE ON VILLAGE COMMUNITIES CRANGGANG KUDUS}

\begin{abstract}
Nowadays, environmental problems still arise and cannot be resolved properly; one of them is environmental sanitation which includes trush management, waste management, clean water supply and toilet provision. Behavior is one of factors affecting the scope of environmental sanitation in an area. Behavior that is continuously carried out will become a culture in the community. If it is good, it will become a positive culture, on the other side, if it is bad, it will become a negative culture in the community. The aim of this study is to determine the behavior and culture of environmental sanitation at Cranggang Village. This study is qualitative study with 7 informants. The instruments used in this study are manual interview, recording devices and camera. Analysis method used thematic context analysis. The community sanitation behavior is quite good while in the aspect of trash management, it is still not good. The community do not know about local regulations on trash management, however, the community has desire to relize village regulations, so, it will change their environmental sanitation behavior. The community hopes that there will be a temporary trash management facility at village level. So, it can manage trash community management properly.
\end{abstract}

Keywrds: Policy, culture, sanitation

\begin{abstract}
Abstrak
Masalah lingkungan hidup masih muncul dan belum bisa teratasi dengan baik saat ini, salah satunya sanitasi lingkungan yang meliputi pengelolaan sampah, pengelolaan limbah, penyediaan air bersih, dan penyediaan jamban. Perilaku menjadi salah satu factor yang mempengaruhi cakupan sanitasi lingkungan di suatu daerah. Perilaku yang secara terus menerus dilakukan akan menjadi budaya di masyarakat. Apabila perilakunya baik maka akan menjadi budaya yang positif, dan sebaliknya apabila perilakunya buruk maka akan menjadi budaya negatif dimasyarakat. Penelitian ini bertujuan untuk mengetahui perilaku dan budaya sanitasi lingkungan di Desa Cranggang. Jenis penelitian ini adalah penelitian kualitatif, dengan jumlah informan 7 orang. Instrument penelitian menggunakan panduan wawancara, alat perekam, dan kamera. Metode analisis menggunakan thematic content analysis. Perilaku sanitasi masyarakat cukup baik, hanya pada aspek pengelolaan sampah saja yang masih kurang baik. Masyarakat belum mengetahui adanya peraturan daerah tentang pengelolaan sampah, namun masyarakat punya kemauan untuk mewujudkan peraturan desa tersebut sehingga berubah perilaku sanitasi lingkunganya. Harapan masyarakat agar tersedia tempat pengelolaan sampah sementara di tingkat desa, sehingga pengelolaan sampah masyarakat bisa dikelola dengan baik.

Kata kunci: Kebijakan,budaya,sanitasi
\end{abstract}




\section{PENDAHULUAN}

Indonesia merupakan salah satu Negara di dunia yang memiliki potensi kekayaan alam yang luar biasa banyak. Ditambah dengan terus meningkatknya jumlah penduduk setiap tahunya. Namun, dengan banyaknya potensi tersebut, masih menyisakan tugas rumah yang cukup besar terutama dalam pengelolaan lingkungan hidup. Beberapa permasalahan lingkungan hidup yang masih muncul dan belum bisa teratasi dengan baik saat ini adalah masalah sanitasi lingkungan meliputi pengelolaan sampah, pengelolaan limbah, penyediaan air bersih, dan penyediaan jamban sehat.

Berdasarkan data dari Kementerian Lingkungan Hidup dan Kementerian Perindustrian Republik Indonesia tahun 2016 total jumlah timbunan sampah yang dihasilkan masyarakat Indonesia sebesar 65,2 juta ton per tahun. Sedangkan limbah B3 yang dikelola pada tahun 2017 adalah 60,31 juta ton. Kualitas air sungai di Indonesia umumnya juga berada pada status tercemar berat. Tahun 2018 25,1 persen desa mengalami pencemaran air, dan sekitar 2,7 persen desa tercemar tanahnya. Pencemaran air tanah ini menimbulkan dampak terjadi banjir di sejumlah daerah di Indonesia. Tercatat dari tahun 2016 - 2017 terdapat 1.805 titik banjir yang menyebabkan 433 korban jiwa. Kondisi ini diperparah dengan tingginya angka kematian kasar (CFR) diare di Indonesia. Pada tahun 2016 tercatat CFR diare di Indonesia mencapai 3,04 persen, padahal diharapkan kurang dari 1 persen. ${ }^{1}$

Melalui keputusan Menteri Kesehatan Nomor 852/Menkes/SK/IX/2008 yang kemudian diperkuat menjadi Peraturan Menteri Kesehatan Nomor 3 tahun 2014, Sanitasi Total Berbasis Masyarakat (STBM) dikukuhkan sebagai strategi nasional pembangunan sanitasi di Indonesia. Peraturan Menteri Kesehatan Republik Indonesia Nomor 3 Tahun 2014 Tentang Sanitasi Total Berbasis Masyarakat menyatakan bahwa dalam rangka memperkuat upaya perilaku hidup bersih dan sehat, mencegah penyebaran penyakit berbasis lingkungan, meningkatkan kemampuan masyarakat, serta meningkatkan akses air minum dan sanitasi dasar, perlu menyelenggarakan sanitasi total berbasis masyarakat. Hal ini bertujuan untuk mewujudkan perilaku masyarakat yang higienis dan saniter secara mandiri dalam rangka meningkatkan derajat kesehatan masyarakat yang setinggitingginya. $^{2}$ 
Kabupaten Kudus merupakan salah satu kabupaten yang ada di Jawa Tengah. Cakupan sanitasi layak di kabupaten ini yang tercermin dari laporan sanitasi total berbasis masyarakat (STBM) tahun 2015 baru sekitar 22 persen desa di kabupaten kudus yang laik STBM. Komponen STBM tersebut antara lain mewujudkan komunitas yang bebas buang besar di sembarang tempat, setiap rumah tangga telah menerapkan pengelolaan air minum dan makanan yang aman di rumah tangga, setiap rumah tangga dan sarana pelayan umum dalam sauatu komunitas telah menyediakan fasilitas cuci tangan, setiap rumah tangga mengelola limbanya dengan benar, dan setiap rumah tangga mengelola sampahnya dengan benar. Rendahnya cakupan sanitasi layak ini berdampak pada tingginya angka kesakitan diare di Kabupaten Kudus. Berdasarkan data dari Dinas Kabupaten Kudus tahun 2015 tercatat kasus diare yang telah ditangani sebanyak 17.945 kasus, dengan angka morbiditas 214 per 1000 penduduk. $^{3}$

Salah satu factor yang menyebabkan rendahnya cakupan sanitasi lingkungan ini adalah factor perilaku masyarakat. Menurut HL Blum kondisi lingkungan dan perilaku lah yang secara berurutan mempunyai andil paling besar terhadap status kesehatan masyarakat. Menurut Notoatmodjo (2003) dalam Kasnodihardjo (2013) mengatakan bahwa perilaku manusia yang pada dasarnya adalah aktivitas manusia merupakan respons seseorang (organism) terhadap stimulus yang berhubungan dengan sakit dan penyakit. Perilaku tersebut meliputi peningkatan dan pemeliharaan kesehatan, pencegahan penyakit, pencarian pengobatan, sistem pelayanan kesehatan, makanan, serta lingkungan. ${ }^{4}$ Perilaku sanitasi lingkungan merupakan perilaku kesehatan preventif seseorang maupun kelompok dalam upaya pencegahan penyakit yang akan timbul melalui pengelolaan lingkungan, baik lingkungan bagi dirinya sendiri maupun sekitar. Perilaku sanitasi lingkungan dapat pula diartikan sebagai kegiatan yang ditujukan untuk meningkatkan dan mempertahankan standar kondisi lingkungan yang mendasar yang mempengaruhi kesejahteraan manusia. $^{5}$

Berdasarkan data studi pendahuluan yang telah dilakukan diketahui penduduk Desa Cranggang secara umum memiliki pengatahuan yang baik mengenai sanitasi lingkungan. $\quad 75 \%$ responden berpengatahuan baik, hanya $25 \%$ saja yang pengetahuan tentang sanitasi lingkungannya yang kurang. Sedangkan sikap responden 
bertolak belakang dengan pengetahuan. Berdasarkan hasil studi pendahuluan hanya $5 \%$ responden saja yang mempunya sikap baik, dan 95\% responden memiliki sikap kurang. Selain itu, berdasarkan hasil observasi yang telah dilakukan masih banyak warga yang masih membuang sampah sembarangan di sungai dan kebun. Masih terdapat warga yang membakar sampahnya di pekarangan rumah, dan beberapa fenomena kesehatan lingkungan lain.

Hasil ini dikuatkan dengan penelitian yang telah dilakukan David dan Ervi tahun 2018. Berdasarkan hasil penelitian ini diketahui rata-rata pengetahuan dan sikap masyarakat Desa Cranggang tentang sanitasi lingkungan sudah cukup baik ditunjukan dengan ratarata nilai skor pengetahuan 77 dan rata-rata skor sikap 68.7 Berdasarkan hasil penelitian tersebut, menunjukan tingginya pemahaman masyarakat Desa Cranggang mengenai sanitasi lingkungan, namun tidak berbanding lurus dengan perilaku untuk menjaga kesehatan lingkungan, karena faktanya masih ditemukan masyarakat yang membuang sampah dan limbah di sungai, serta memanfaatkan air sungai sebagai sarana MCK. Perilaku yang secara terus menerus dilakukan akan menjadi sebuah kebiasaan dan budaya bagi masyarakat yang sulit untuk dirubah. ${ }^{6}$

Berdasarkan latar belakang tersebut, peneliti tertarik untuk menggali lebih dalam mengenai faktor lain yang menyebabkan masih buruknya kondisi sanitasi lingkungan di Desa Cranggang. Salah satu aspek yang yang menjadi kajian dalam penelitian ini adalah perilaku dan budaya masyarakat Desa Cranggang mengenai sanitasi lingkungan.

\section{BAHAN DAN METODE}

Jenis dan rancangan penelitian yang digunakan pada penelitian ini adalah studi kualitatif. Dimulai dari pengumpulan data sampai pengambilan kesimpulan secara umum. Penelitian kualitatif dipilih karena lebih sensitif dan adaptif terhadap peran dan berbagai pengaruh yang timbul. Disamping itu, karena peneliti akan mencoba menggali atau mengeskplorasi, pengetahuan bagaimana kenyataan yang ada di lapangan. ${ }^{7}$ Rancangan penelitian kualitatif ini menggunakan pendekatan Etnografi, yaitu salah satu metode ilmiah dalam penelitian yang mendefinisikan kebudayaan sebagai pengetahuan yang diperoleh manusia dan digunakan untuk menafsirkan pengalaman dan menimbulkan perilaku. ${ }^{8}$ 
Penelitian dilakukan di Desa Cranggang Kecamatan Dawe Kabupaten Kudus pada bulan Mei sampai dengan Juni 2019. Pengambilan sumber data penelitian ini menggunakan tehnik Purposive Sampling, yaitu pengambilan sampel didasarkan pada pilihan penelitian tentang aspek apa dan siapa yang dijadikan fokus pada situasi tertentu dan saat ini terus menerus sepanjang penelitian. ${ }^{7}$ Subjek penelitian terdiri dari 7 orang yaitu 1 orang Kepala Desa, 1 orang tenaga kesehatan, 1 orang Pengurus FKD/Kader Kesehatan Desa, dan 4 orang tokoh masyarakat.

Proses pengumpulan data dalam penelitian ini menggunakan instrument pedoman wawancara, tape recorder, dan kamera. Sedangkan proses pengolahan data diawali dengan mentranskripsikan seluruh data secara utuh berdasarkan topik, dikembangkan ke bentuk bahasa yang lebih baku, secara naratif dan direduksi dalam rangkuman. Kemudian data dianalisis menggunakan metode Tematic Content Analysis (TCA) yaitu menganalisis dan menyimpulkan isi dari tema yang dipilih. Selanjutnya dilakukan pengelompokan untuk mencari keterkaitan antar berbagai variabel tersebut. $^{7}$

HASIL

Penelitian tentang perilaku sanitasi di Desa Cranggang ini dilakukan pada 7 orang informan, dengan karakteristik sebagai berikut:

Tabel 1. Karakteristik Informan Penelitian

\begin{tabular}{cccll}
\hline No & Informan & Usia (tahun) & Pendidikan & \multicolumn{1}{c}{ Jabatan } \\
\hline 1 & Informan 1 & 53 & SMA & Kepala Desa \\
2 & Informan 2 & 49 & SMA & Ketua FKD \\
3 & Informan 3 & 33 & Diploma & Bidan Desa \\
4 & Informan 4 & 45 & SMA & Tokoh Masyarakat \\
5 & Informan 5 & 36 & SMA & Tokoh Masyarakat \\
6 & Informan 6 & 50 & SMA & Tokoh Masyarakat \\
7 & Informan 7 & 25 & Sarjana & Pengurus Karang Taruna \\
\hline
\end{tabular}

Infroman dalam penelitian ini terdiri dari beberapa latar belakang pendidikan, mulai dari SMA sampai dengan sarjana. Selain itu, peneliti juga mengambil informan yang berasal dari semua kalangan, agar terdapat keterwakilan di setiap bidang. Dalam penelitian ini informan berasal dari kalangan pemerintah desa, petugas kesehatan, tokoh masyarakat, dan tokoh muda. Harapanya dengan keberagaman karakteristik informan menjadikan data 
dan informasi yang dikumpulkan dalam penelitian ini dapat mereprentasikan gambaran dilapangan secara utuh.

\section{Perilaku Sanitasi Lingkungan}

Perilaku sanitasi masyarakat Desa Cranggang merupakan gambaran umum pengetahun, sikap, dan praktek masyarakat informasi bahwa masyarakat Desa Cranggang secara umum memiliki perilaku sanitasi yang cukup baik, hanya dalam aspek pengelolaan sampah rumah tangga saja yang masih kurang baik perilakunya. Sedangkan untuk aspek sanitasi lain masyarakat desa sudah berperilaku baik.

Desa Cranggang tentang sanitasi.

Berdasarkan hasil penelitian diperoleh

Kotak 1

“.... warga sudah sering diingatkan mengenai sampah, namun belum berubah perilakunya.....” (INF 1)

“.... iya, perilaku sanitasi masyarakat di Desa Cranggang memang masih kurang, biasanya masih ada yang membuang sampah di dekat jembatan.....” (INF 2)

“.....perilaku masyarakat Desa Cranggang untuk masalah sanitasi cuci sudah bagus, BAB sudah bagus, tapi untuk buang sampah masih menjadi masalah.....” (INF 3)

“.... kalo sanitasi insya allah sudah oke, Cuma pelaksanaan belum maksimal.....” (INF 4)

“..... kalo perilaku kembali ke orang masing-masing, kalo pengetahuan sudah tau, tapi praktiknya yang kurang.....” (INF 5)

“.... kalo menurut saya memang masalah kebersihan masyarakat masih kurang, terutama masalah sampah....” (INF 6)

“.... Tidak bisa dipungkiri pak, memang masalah perilaku masyarakat Desa Cranggang masih kurang. Sebenarnya warga tau, tapi memang perilakunya itu loh pak.....” (NF 7)

\section{Pengembangan Kebijakan Perilaku}

\section{Sanitasi Lingkungan}

Berdasarkan hasil observasi dan wawancara yang telah dilakukan, diperoleh hasil sebagai berikut :
1. Informan belum mengetahui adanya Peraturan Daerah Kabupaten Kudus tentang Pengelolaan Sampah dan belum pernah ada sosialisasi dari pihak Pemerintah Kabupaten atau Dinas terkait tentang peraturan ini. 
2. Di Desa Cranggang belum ada kebijakan mengenai pengelolaan sampah

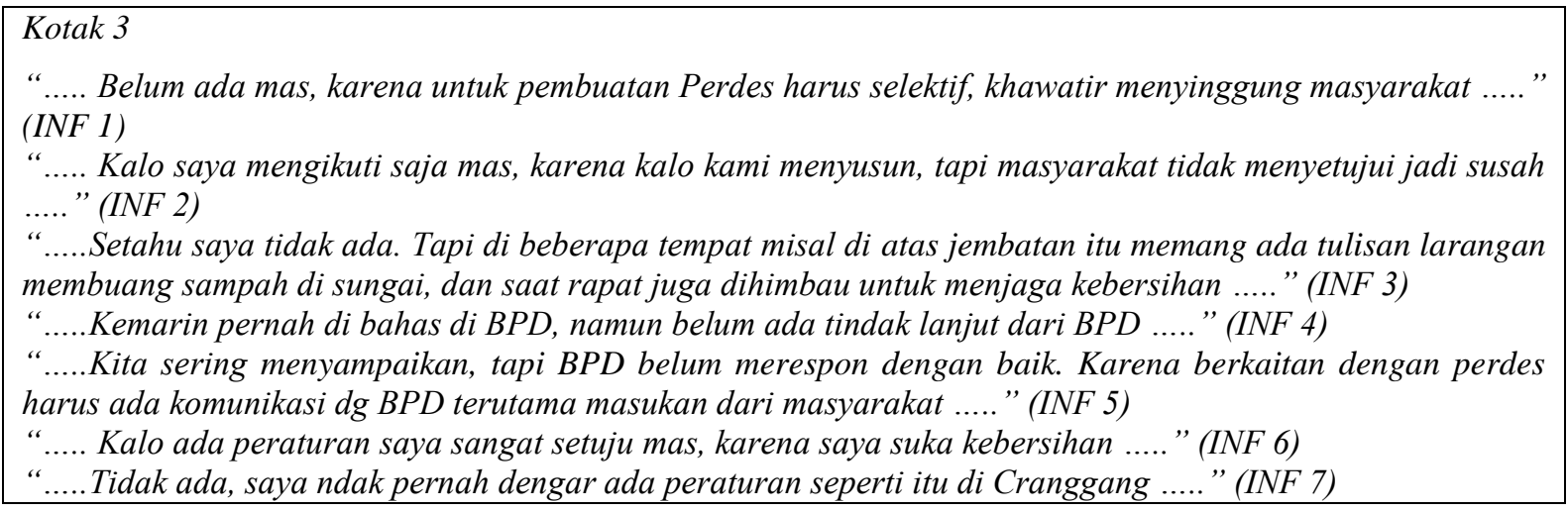

3. Pemerintah Desa dan Masyarakat berkomitmen untuk melakukan pengelolaan sampah

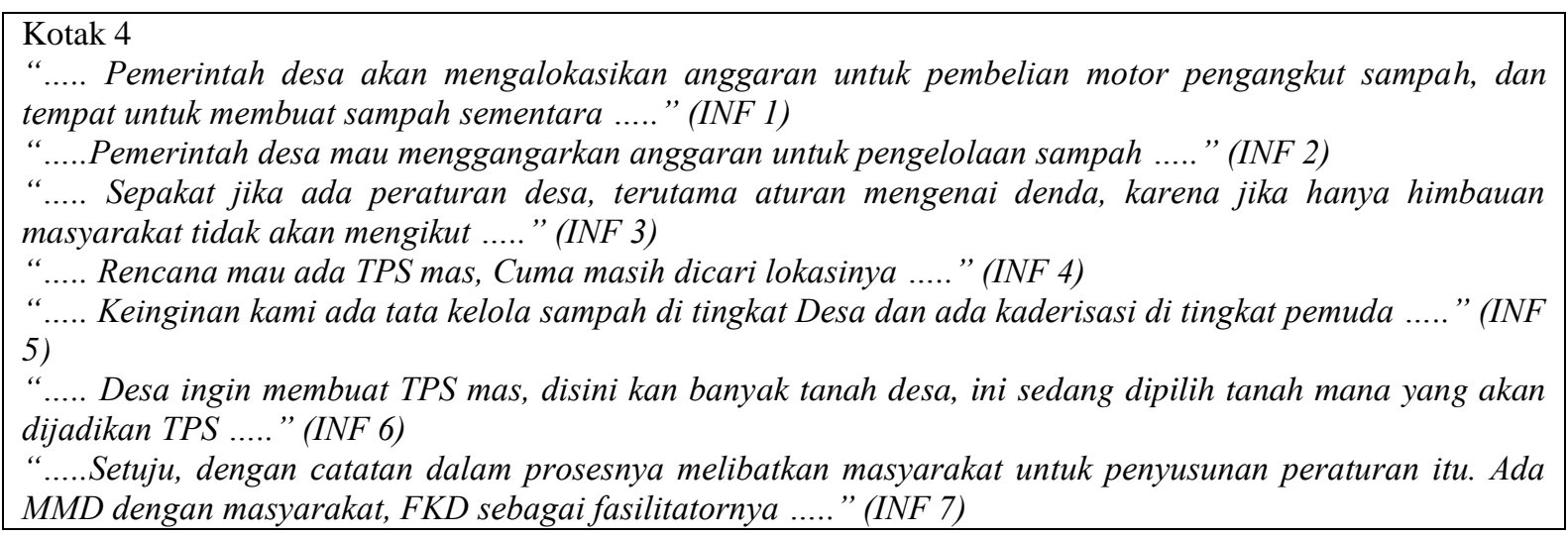

\section{PEMBAHASAN}

\section{Perilaku Sanitasi Lingkungan Masyarakat Desa Cranggang}

Berdasarkan hasil penelitian yang telah dilakukan, secara umum masyarakat Desa Cranggang berperilaku sanitasi baik terutama untuk aspek penyediaan air bersih, pengelolaan limbah rumah tangga, dan penyediaan jamban. Namun untuk pengelolaan sampah, sampai saat ini masih menjadi permasalahan di desat tersebut.

Penyediaan air bersih di Desa Cranggang berasal dari 3 sumber utama.
Pertama sumber air bersih dari mata air pegunungan muria. Air ini digunakan oleh sebagian besar penduduk di satu dusun yang terletak dibagian barat desa. Kedua air bersih dari sumur artesis. Air dari sumber sumur artesis inilah yang paling banyak digunakan oleh masyarakat Desa Cranggang. Seluruh dusun memiliki minimal 1 sumber air jenis ini, hanya dusun yang menggunakan mata air saja yang tidak mempunyai sumur artesis. Dan yang terakhir adalah air bersih dari sumur dangkal. Satu dusun yang terletak di pusat 
pemerintahan Desa Cranggang menggunakan sumber air bersih dari air tanah dangkal. Karena dusun ini terletak di daerah dengan ketinggian terendah di desa ini.

Secara umum masyarakat di Desa Cranggang telah mempunyai instalasi pengolahan air limbah rumah tangga. Masyarakat membangun septictank nya dibelakang rumah mereka, atau menyalurkan limbah cair rumah tangganya ke saluran air yang telah dibuat oleh pemerintah desa. Namun, pemanfaatan saluran air ini belum optimal, karena hanya sebagian kecil saja masyarakat yang memanfaatkanya. Saluran air yang dibuat oleh pemerintah desa hanya digunakan pada saat musim hujan tiba, untuk mengalirkan air hujan dari jalan dan gang yang ada di desa. Namun sangat disayangkan, dari hasil wawancara dengan para informan, diketahui masih ditemukan masyarakat yang membuang limbah rumah tangganya di sawah atau kebon rumah.

Masyarakat Desa Cranggang sebagian besar sudah mempunyai jamban di rumahnya. Walaupun terdapat beberapa rumah tangga yang kondisi jambanya belum sesuai memenuhi syarat jamban sehat. Penyediaan jamban di Desa Cranggang juga baru terlaksana 100\% pada tahun 2010 an. Berdasarkan informasi dari informan penelitian diketahui pemerintah desa mendapatkan bantuan dari Pemerintah Kabupaten Kudus berupa pemasangan jamban di rumah tangga. Namun bantuan yang diberikan oleh pemerintah hanya cukup untuk membeli kloset saja. Sehingga saat ini, masih ditemukan jamban yang tidak memenuhi syarat kesehatan.

Satu-satunya aspek yang masih menjadi permasalahan sampai saat ini adalah belum adanya pengelolaan sampah yang dihasilkan oleh masyarakat Desa Cranggang. Hingga saat ini belum ada model pengelolaan sampah di Desa Cranggang yang dilakukan oleh masyarakat. Masyarakat masih banyak yang mengelola sampah secara mandiri di rumah masing-masing dengan cara membakar sampah. Bahkan muncul budaya di masyarakat yaitu membakar sampah sebagai salah satu upaya untuk mengusir nyamuk atau ngengat yang menggangu ternak-ternak masyarakat. Selain itu, berdasarkan hasil observasi dari peneliti diketahui terdapat satu lokasi yang menjadi tempat pembuangan akhir sampah masyarakat Desa Cranggang, namun sebenarnya lokasi tersebut merupakan tanah milik masyarakat yang bukan 
diperuntukan untuk pengelolaan sampah. Hasil wawancara penulis dengan informan diketahui sebenarnya masyarakat sudah sering mendapatkan informasi dalam bentuk penyuluhan dari petugas kesehatan Puskesmas setempat terkait pengelolaan sampah dan beberapa bahayanya apabila tidak mengelola sampah dengan baik. Namun, hal ini tidak menjadikan masyarakat jera dan merubah perilakunya.

David dan Ervi dalam penelitiannya menyampaikan bahwa pengetahuan masyarakat Desa Cranggang baik dengan rata-rata skor nilai pengetahuan pre test 77 dan skor posttest $88.7 \mathrm{Hal}$ ini menunjukan bahwa, masyarakat secara umum sudah mengetahui mengenai sampah dan bahaya yang dihasilkan sampah apabila tidak dikelola dengan baik. Namun dalam prakteknya masyarakat masih belum bisa mengelola sampah dengan baik. ${ }^{6}$

Menurut Silvia (2013) dalam penelitianya menyampaikan penyebab perilaku yang salah mengenai hygiene dan sanitasi adalah karena pengetahuan yang rendah atau ketidaktahuan tentang hal-hal yang seharusnya diketahui. Berdasarkan penelitian yang dilakukan rata-rata pengetahuan responden sebelum diberikan intervensi adalah 38,64, dan perilaku sebelum diberikan intervensi adalah 29,27.
Sedangkan pengetahuan setelah diberikan intervensi adalah 41,64, dan perilaku setelah diberikan intervensi adalah 32,09. Terdapat perbedaan yang signifikan pengetahuan dan perilaku sebelum dan sesudah diberikan intervensi, artinya intervensi dengan pemberian informasi atau edukasi kepada responden dapat meningkatkan pengetahuan dan perilaku responden. ${ }^{9}$

Selain itu, dalam penelitian lain Handayani, Adhi, dan Duarsa (2015) menyatakan bahwa pengetahuan dan sikap berhubungan dengan perilaku responden dengan nilai $\mathrm{p}$ value 0,001 . Perilaku seseorang sangat berkaitan dengan tingkat pengetahuannya. Pengetahuan itu dapat berasalh dari pemberian informasi oleh perusahaan atau dinas kesehatan. Pemberian informasi ini bertujuan untuk meningkatkan pengetahuan. ${ }^{10}$

\section{Pengembangan Kebijakan Perilaku Sanitasi Lingkungan}

Pemerintah Kabupaten Kudus telah mengeluarkan peraturan daerah tentang pengelolaan sampah pada tahun 2017. Peraturan ini merupakan turunan dari Undang-Undang sampah nomor 18 tahun 2008. Dalam Peraturan Daerah Kabupaten Kudus nomor 4 tahun 2017 ini diatur 
mengenai mekanisme pengelolaan sampah, mulai dari sumber sampai pengelolaan akhir. Masyarakat atau swasta boleh mengelola sampahnya sendiri dengan ijin pemerintah daerah. Pemerintah juga mendorong pengelolaan sampah sudah dimulai dari sumber yaitu rumah tangga. Sehingga sampah yang masuk ke tempat pengolahan akhir (TPA) Tanjungrejo Kudus semakin berkurang volumenya. ${ }^{11}$

Desa Cranggang sebagai salah satu desa yang ada di Kabupaten Kudus juga diharapkan dapat berperan aktif dalam permasalahan sampah. Apalagi sampah masih menjadi permasalahan utama di Desa ini. Perlu ada perhatian khusus dari pemerintah desa pada aspek pengelolaan sampah. Karena untuk aspek sanitasi lain, secara umum sudah dikelola dengan baik oleh masyarakat desa.

Berdasarkan hasil observasi dan wawancara peneliti diketahui saat ini pemerintah desa sudah berkomitmen meningkatkan kualitas penyediaan sanitasi dasar di Desa Cranggang utamanya untuk tiga komponen sanitisi dasar yaitu penyediaan air bersih, penyediaan jamban, dan pengelolaan limbah rumah tangga. Kebijakan dalam penyediaan air bersih yang dikeluarkan pemerintah desa adalah dengan membuat beberapa sumur artesis guna meningkatkan cakupan air bersih masyarakat. Aspek penyediaan jamban, pemerintah desa melakukan program jambanisasi dengan mengakses pendanaan dan hibah dari pemerintah kabupaten guna meningkatkan cakupan kepemilikan jamban sehat di rumah tangga. Dan untuk pengelolaan limbah rumah tangga, pemerintah desa memfasilitasi masyarakat dengan membangun saluran air limbah komunal yang berada di semua dusun di Desa Cranggang. Sedangkan untuk aspek pengelolaan sampah, sampai saat ini belum ada kebijakan dan program yang dilakukan pemerintah desa untuk mengatasi ini, baru sebatas himbauan saja kepada masyarakat untuk tidak membuang sampah di sungai.

Sampai saat ini belum pernah dilakukan sosialisasi Peraturan Daerah Kabupaten Kudus No. 4 Tahun 2017 di Desa Cranggang, sehingga pemerintah desa juga belum mengambil tindakan apapun baik dalam bentuk kebijakan ataupun program terkait pengelolaan sampah. Pemerintah desa khawatir, karena dengan tidak adanya aturan dasar mengenai pengelolaan sampah sehingga akan timbul permasalahan di masyarakat apabila pemerintah desa mengeluarkan kebijakan berupa peraturan desa mengenai pengelolaan sampah di Cranggang. Dalam 
bentuk kebijakan, opaya penyusunan peraturan desa ini sudah muncul di kalangan tokoh masyarakat di Desa Cranggang, namun sampai sekarang belum bisa dilaksanakan karena ketidak tahuan para tokoh masyarakat terkait adanya peraturan daerah yang dapat menjadi dasar pembuatan peraturan desa. Sedangkan dalam aspek program, pemerintah Desa Cranggang berencana membuat tempat penampungan sampah sementara yang bersifat komunal di salah satu dusun di Desa Cranggang. Perencanaan sudah dimulai dari tahun 2019 ini, dengan melakukan pemetaan wilayah yang berpotensi dapat dijadikan lokasi TPS komunal itu. Rencananya jika semua persiapan sudah siap, dan lokasi sudah ditentukan, maka pembangunan TPS komunal ini akan dimasukan dalam APDes tahun 2020, sehingga masyarakat Desa Cranggang dapat membuang sampahnya di TPS tersebut, dan terwujud Desa Cranggang yang bersih dan memiliki cakupan sanitasi baik.

Mulasari, Husodo, dan Muhadjir (2014) dalam penelitianya menyampaikan dampak kebijakan pengelolaan sampah pada perubahan kualitas lingkungan dan kesehatan masyarakat di lima kabupaten/kota di DIY relatif sama, yaitu bersih, asri, dan nyaman. Pemerintah lewat kebijakannya mendorong keterlibatan aktif masyarakat dalam mengelola sampah. Hal tersebut diharapkan dapat mengubah perilaku masyarakat sehingga daya dukung lingkungan dapat terus dirasakan oleh masyarakat. Keuntungan ekonomi diperoleh masyarakat ketika mau mengelola sampah secara mandiri. Penelitian ini juga menjelaskan mengenai faktor-faktor yang memengaruhi permasalahan sampah di DIY diantaranya adalah perilaku sadar lingkungan dan masalah ekonomi (retribusi). Tingkat pengetahuan dan sikap masyarakat tentang pengelolaan sampah di daerah pedesaan kemungkinan masih rendah sehingga memengaruhi perilaku sadar lingkungan. Hal ini pula yang menjadi dasar adanya kebijakan mengenai pengelolaan sampah di DIY. ${ }^{12}$

\section{KESIMPULAN}

Masyarakat Desa Cranggang secara umum berperilaku sanitasi baik khususnya dalam penyediaan air bersih, penyediaan jamban, dan pengelolaan limbah cair rumah tangga, namun masyarakat masih kurang baik dalam pengelolaan sampah. Salah satu upaya yang ingin dilakukan pemerintah desa adalah dengan program 
pembangunan TPS. Program ini dapat berjalan lebih optimal jika dibarengi dengan adanya peraturan desa mengenai pengelolaan sampah.

\section{UCAPAN TERIMA KASIH}

Ucapan terima kasih disampaikan kepada DRPM Kementerian Riset dan Pendidikan Tinggi Republik Indonesia atas Hibah Proposal Dosen Pemula dengan Surat Perjanjian Kontrak PDP Nomor 063/L6/AK/SP2H/PENELITIAN/2019

tanggal 8 April 2019.

\section{DAFTAR RUJUKAN}

1. Safitri, Pramudya Ajeng, Purba Winda Sartika, Zulkifli Muchammad. Statistik lingkungan hidup Indonesia Tahun 2018. Badan Pusat Statistik Indonesia. Jakarta. 2018.

2. Permenkes RI. 2014. Sanitasi Total Berbasis Masyarakat. Jakarta : Permenkes RI

3. Dinkes Kudus. PROFIL KESEHATAN KABUPATEN KUDUS TAHUN 2015. Dinas Kesehatan Kabupaten Kudus. Kudus. 2015.

4. Kasnodihardjo, Elsa Elsi. Deskripsi Sanitasi Lingkungan, Perilaku Ibu, dan Kesehatan Anak. Jurnal Kesehatan Masyarakat Nasional. Vol 7 No. 9 April 2013. :415-20.
5. Notoatmodjo, Soekidjo. 2010. Promosi Kesehatan Teori \& Aplikasi. Jakarta : PT Rineka Cipta.

6. Caesar DL, Dewi ER. 2018. PENGARUH MEDIA BUKU SAKU TERHADAP PENGETAHUAN TENTANG SANITASI LINGKUNGAN PADA KADER KESEHATAN DESA CRANGGANG. Jurnal Kesehatan Masyarakat (JKM) CENDEKIA UTAMA. 2018 Aug 28;6(2):137-46.

7. Sugiono. Memahami Penelitian Kualitatif. Alfabeta: Bandung. 2009

8. Moleong. 2009. Metodologi Penelitian Kualitatif. Remaja Rosdakarya: Bandung.

9. Wagustina S. PENGARUH PELATIHAN HYGIENE DAN SANITASI TERHADAP PENGETAHUAN DAN PERILAKU PENJAMAH MAKANAN DI INSTALAASI GIZI RUMAH SAKIT UMUM DAERAH MEURAXA BANDA ACEH. Jurnal Ilmiah STIKes U'Budiyah Vol. 2013;2(1).

10. Handayani NM, Adhi KT, Duarsa DP, Handayani NM, Adhi KT, Duarsa DP. Faktor yang mempengaruhi perilaku penjamah makanan dalam penerapan cara pengolahan pangan yang baik pada industri rumah tangga pangan di Kabupaten Karangasem. Public Health and Preventive Medicine Archive. 2015 Dec;3(2):194-202.

11. Sekertariat Daerah Kabupaten Kudus. 2017. Peraturan Daerah Kabupaten Kudus Nomor 4 Tahun 2017 tentang Pengelolaan Sampah. Pemerintah Daerah Kudus: Kudus.

12. Mulasari SA, Husodo AH, Muhadjir N. Kebijakan pemerintah dalam pengelolaan sampah domestik. Kesmas: National Public Health Journal. 2014 May 1;8(8):404-10. 